RASĀYAN J. Chem.

Vol. 13 | No. 3 |1894-1903| July - September | 2020

ISSN: 0974-1496 | e-ISSN: 0976-0083 | CODEN: RJCABP

RJC http://www.rasayanjournal.com http://www.rasayanjournal.co.in

\title{
ANTIBACTERIAL ACTIVITY AND MECHANISM OF ACTION OF RARUGADONG (Dioscorea pyrifolia Kunth.) TUBER EXTRACTS ON Escherichia coli AND Staphylococcus aureus CELL LEAKAGE
}

\author{
V.Mierza ${ }^{1,5}$, Rosidah $^{2, *}$, G. Haro ${ }^{3}$ and D. Suryanto ${ }^{4}$ \\ ${ }^{1}$ Department of Pharmaceutical Biology, Faculty of Pharmacy, Universitas Sumatera Utara, \\ Medan, 20155, North Sumatera, Indonesia \\ ${ }^{2}$ Department of Pharmaceutical Pharmacology, Faculty of Pharmacy, Universitas Sumatera \\ Utara, Medan, 20155, North Sumatera, Indonesia \\ ${ }^{3}$ Department of Pharmaceutical Chemistry, Faculty of Pharmacy, Universitas Sumatera Utara, \\ Medan, 20155, North Sumatera, Indonesia \\ ${ }^{4}$ Department of Biological in Faculty of Mathematics and Natural Science, Universitas Sumatera \\ Utara, Medan, 20155, North Sumatera, Indonesia \\ ${ }^{5}$ Faculty of Pharmacy, Universitas Tjut Nyak Dhien, J1. Rasmi No. 28, Medan 20123, North \\ Sumatera, Indonesia \\ *E-mail: rosidah@usu.ac.id
}

\begin{abstract}
Bacterial immunity against antibiotics causes increased mortality. In dealing with this problem, studies have been carried out, one of which is by utilizing natural medicinal materials such as Dioscorea pyrifolia Kunth. tuber. Dioscorea pyrifolia is one of the medicinal plants that have not been widely studied so that in this study antibacterial activity testing will be carried out, the mechanism of action against leakage bacterial cells and component analysis of chemical extracts. Research carried out includes the collection and identification of plants, extraction, determination of antibacterial activity and analysis of chemical compounds using Thin Layer Chromatography; determination of the mechanism of action using an ultraviolet spectrophotometer, atomic absorption spectrometer and scanning electron microscopy. The results of research that have been carried out are known to extract ethyl acetate and methanol which have an inhibitory diameter as antibacterial activity against Escherichia coli and Staphylococcus aureus. The extraction method that produces the strongest antibacterial activity is the multilevel percolation method using ethylacetate as a solvent. The chemical compounds found in ethyl acetate extract are glycosides, alkaloids and polyphenol compounds, such as tannins and flavonoids. The mechanism of bacterial cell leakage caused by Dioscorea pyrifolia tuber extract can be proven by ultraviolet spectrophotometry, atomic absorption spectrophotometer and scanning Electron microscope.
\end{abstract}

Keywords: Dioscorea pyrifolia Kunth., Antibacterial Activity, Mechanism of Action, Thin Layer Chromatography, Escherichia coli, Staphylococcus aureus, Scanning Electron Microscope

(C) RASĀYAN. All rights reserved

\section{INTRODUCTION}

At present, the whole world is facing the problem of antibiotic resistance, both around the environment and in hospitals also other health facilities ${ }^{1}$. The number of infectious diseases caused by bacteria is increasing and spreading of infections so quickly, such as Enterococci that are resistant to vancomisine and various types of Staphylococci, Pneumococci and Streptococci that are resistant to methicilline ${ }^{2-3}$. Until now, there have been many studies of plant secondary metabolites that have antibacterial activity. Phenolic and polyphenol groups are a group of secondary metabolites of plants that almost all have antimicrobial activity, namely phenol groups, phenolic acids, quinones, flavones, flavonoids, flavonols, tannins and coumarins ${ }^{4}$. Research on the mechanism of action of plant secondary metabolites as an Rasayan J. Chem., 13(3), 1894-1903(2020)

http://dx.doi.org/10.31788/ RJC.2020.1335864 
RASĀYAN J. Chem.

Vol. 13 | No. 3 |1894-1903| July - September | 2020

antibacterial is still incomplete and being debated. This is because so complex plant chemical compounds that are in it ${ }^{5}$. Some of these mechanisms of action are not absolute for all plants, but most depend on the composition of secondary metabolites present in each plant species. The choice of extraction solvent depends on the specific nature of the targeted bioactive compound ${ }^{6}$. Therefore, for each species of plant, it is possible to have different extraction processes and types of solvents for different biological activities. Dioscorea sp. is monocotyledonous of Dioscoreaceae family and used as a food ingredient, such as soups and flavors in West Afrika, South Asia and Caribbean ${ }^{7}$. Dioscoreaceae has about 600 species and used as medicinal plants in West African ${ }^{8}$. In Indonesia, the Dioscoreaceae plant of Dioscorea pyrifolia (D. pyrifolia) grows in the Urug Besan Forest, Medan City, North Sumatra Province ${ }^{9}$ and according to the local community, D. pyrifolia tubers are used as a remedy for skin infections, diarrhea, cough, sprue and cough by vomiting of blood. Dioscoreaceae is a group of medicinal plants whose species have not been widely studied, especially $D$. pyrifolia in Indonesia. The previous research ${ }^{10}$ discover that methanol extract of tubers Dioscorea dumetorum (Kunth) Pax and Dioscorea hirtiflora (Linn.) has antioxidant and antibacterial activity also phytochemical observation by obtaining the results of their presence of phenol and flavonoids compounds. The antimicrobial effect of the tuber Dioscorea deltoidea on several microbes ${ }^{11}$ and biological activity against eye infections ${ }^{12}$ have been investigated. Phytochemical analysis and reduction of free radicals from Dioscorea bulbifera have been investigated ${ }^{13}$. The same species has also been carried out isolation of diosgenin compounds for the treatment of type 2 diabetes mellitus ${ }^{14}$. Diosgenin compounds have also been isolated from Dioscorea zingiberensis ${ }^{15}$ and the identification of diosgenin in several species of Dioscorea ${ }^{16}$. The antidiabetic effect of Dioscorea batatas has also been reported $^{17}$. The steroidal saponin group of Dioscorea nipponica has been isolated ${ }^{18}$. According to data collected by the previous research ${ }^{8}$, has been found in several species of Dioscorea, a new source of essential oils. Dioscorea esculenta has been found as an anti-inflammatory potential ${ }^{19}$. Evaluation of phytonutrients and vitamins has been done on the type of Dioscorea belophylla ${ }^{20}$. In 2012, also investigated the antimicrobial bioefication of extracts of soxletation method using various solvents against Dioscorea pentaphylla found in India ${ }^{21}$. According to data collected by previous research ${ }^{22}$, Dioscorea bulbifera L. and Dioscorea opposittofolia L. have been developed in the form of nanoparticles for antimicrobial activity. In 2012, discovered the antibacterial activity of Dioscorea bulbifera on their extracts, fractions and compounds ${ }^{23}$. Based on chemotaxonomy, plants of the same taxa have a very close kinship, especially at the family, genus and species. The existence of a close relationship that allows the similarity of substances contained in $\mathrm{it}^{24}$ so it is possible to have biological activity that is almost the same. The object of this research is to extract active compounds of D. pyrifolia (rarugadong) tubers from North Sumatera - Indonesia and evaluate their antibacterial mechanism. To our best of knowledge so far there are no studies on the activity antibacterial and mechanism of action of $D$. pyrifolia tuber extracts against Escherichia coli and Staphylococcus aureus. Thus, this study brings novel and valuable information to this area.

\section{Preparation and Identification of Plant Materials}

\section{EXPERIMENTAL}

D. pyrifolia (Rarugadong) tubers came from Urug Besan forest in North Sumatera - Indonesia. The plant was identified by the taxonomist responsible in the Research Center in the Indonesian Institute of Sciences (LIPI) - Bogor, Indonesia.

\section{Extraction Procedure}

Extracts were obtained by the methods of percolation. Powdered simplicia (500 g) were extracted successively with hexane, ethyl acetate and methanol by using percolator at a room temperature. ${ }^{25}$

\section{Procedure of Phytochemical Analysis}

Three types of extracts solution (hexane, ethyl acetate and methanol) each one was prepared by $0.5 \mathrm{~g}$ of an extract with each solvent. Chemical constituents of the extracts were separated using a stationary phase (aluminum plates, silica gel $60 \mathrm{~F}_{254}, \mathrm{Merck}^{\circledR}$ ) on thin-layer chromatography (TLC) system. TLC plates were developed under saturated conditions with two of the eluent systems (mobile phase), i.e., hexane: ethyl acetate (70:30) (non-polar mobile phase for hexane extract) and hexane: ethyl acetate (30:70) (polar 
RASĀYAN J. Chem.

Vol. 13 | No. 3 |1894-1903| July - September | 2020

mobile phase for ethyl acetate and methanol extract). Visualization of separated chemical compound groups with spray reagents to reveal spots of all different groups using $\mathrm{H}_{2} \mathrm{SO}_{4} 10 \%$ in methanol (after spraying, the chromatograms were heated at $100^{\circ} \mathrm{C}$ in an oven to allow for optimal color development), Dragendorff reagent for alkaloids, Liebermann-Burchard for steroids and triterpenoids and $\mathrm{FeCl}_{3} 5 \%$ reagent for polyphenol groups. ${ }^{26-29}$

\section{Procedure of Antibacterial Activities Assays}

Antibacterial activities of extracts were examined by agar well plate diffusion assay method, minimum inhibitory concentration (MIC) and minimum bactericidal concentration (MBC). The examination was carried out based on the previous procedure ${ }^{30}$ that using Mueller Hinton Agar (MHA, Merck ${ }^{\circledR}$ ) as test media and pure bacteria culture (Escherichia coli ATCC 25922 and Staphylococcus aureus 6538, CultiLoops $^{\mathrm{TM}}$ ) with several treatment modifications. Negative blanks used a mixture of dimethylsulfoxide (DMSO, Merck ${ }^{\circledR}$ ) and ethanol (Merck $\left.{ }^{\circledR}\right)$ while positive blanks used chloramphenicol (SERVA®) solution of $2.5 \mathrm{mg} / \mathrm{ml}$. All treatments were carried out 6 repetitions. The determination of the MIC was carried out macrodilution technique ${ }^{30}$ that using Mueller Hinton Broth (MHB, Merck $\left.{ }^{\circledR}\right)$ as test media with some modifications. The MBC value was determined from the results of the agar medium which showed no growth of bacterial colonies after 24-hour incubation at $35 \pm 2^{\circ} \mathrm{C}$.

\section{Procedure for Determination Leakage of Cellular Metabolites}

Determination leakage of cellular metabolites based on the previous literature ${ }^{31}$ with several modifications using a spectrophotometer (ultraviolet-visible Spectrophotometer (UVS) using PharmaSpec 1700 $\left(\right.$ Shimadzu $\left.^{\circledR}\right)$. Measurements were carried out in the Faculty of Pharmacy at the University of Tjut Nyak Dhien, North Sumatra, Indonesia. A total of $5 \mathrm{ml}$ of MHB included bacterial inoculum suspension by 1 $\mathrm{ml}$, then added extract, positive control and negative control of $1 \mathrm{ml}$ each. Then incubated in an incubator of $35 \pm 2{ }^{\circ} \mathrm{C}$ for 24 hours under aerobic conditions. After that, the solution was centrifuged at $3500 \mathrm{rpm}$ for 30 minutes, then supernatant was separated from the cell precipitate. The absorbance of the supernatant was immediately measured with a spectrophotometer. The procedure was carried out six repetitions.

\section{Procedure for Determination of $\mathrm{Ca}^{2+}$ and $\mathrm{K}^{+}$Ions Leakage}

The supernatant solution to be tested was obtained from the same procedure as determining the leakage of cellular metabolites. Procedure for determining $\mathrm{Ca}^{2+}$ and $\mathrm{K}^{+}$ions leakage based on previous literature with some modifications ${ }^{31}$. The supernatant solution to be tested was added with concentrated nitric acid and then allowed to stand for 24 hours, afterward added aqua deionized. The supernatant solution was heated on a hot plate until the volume was half to the previous. The results were added to a flask $(10 \mathrm{ml})$ and then aqua deionized was added to $10 \mathrm{ml}$, then filtered. The filtrate was immediately measured using Z-2000 (Hitachi ${ }^{\circledR}$ ) of Atomic Absorption Spectroscopy (AAS) in the Faculty of Pharmacy at the Universitas Sumatera Utara, North Sumatra, Indonesia. The procedure was carried out six repetitions.

\section{Procedure of Scanning Electron Microscopy (SEM) Analysis}

SEM analysis using the method described by previous research ${ }^{32}$ with slight modifications. One colony from bacterial culture was inoculated into $5 \mathrm{ml} \mathrm{MHB}$, then incubated for 18 hours at $35 \pm 2^{\circ} \mathrm{C}$. After that $0.1 \mathrm{ml}$ of culture, the suspension was re-inoculated into each of $5 \mathrm{ml} \mathrm{MHB}$ containing $0.1 \mathrm{ml}$ of various extracts with a concentration of $100 \mathrm{mg} / \mathrm{ml}$, then incubated at $35 \pm 2{ }^{\circ} \mathrm{C}$ for 12 hours. Cell pellets were collected by soaking with $5 \%$ glutaraldehyde in cacodylate buffer $(0.1 \mathrm{M}, \mathrm{pH} 7.2)$ at $4^{\circ} \mathrm{C}$ for 1.5 hours then centrifuged $8000 \mathrm{rpm}$ for 30 minutes. Then the cell pellets were soaked for 1 hour with osmium tetroxide $(1 \%)$ in cacodylate buffer $(0.1 \mathrm{M}, \mathrm{pH} 7.4)$ at $4^{\circ} \mathrm{C}$. All samples were each dried sequentially with $30 \%, 50 \%, 70 \%, 90 \%$ and $96 \%$ of ethanol at room temperature. The dried sample was treated by gold covered with catholic spraying; analysis was examined by JEOL-JSM-6510LA Scanning Electron Microscope (Scanning Electron Microscope Laboratory, Institut Teknologi Bandung, West Java, Indonesia). 
RASĀYAN J. Chem.

Vol. 13 | No. 3 |1894-1903| July - September | 2020

\section{Statistical Analysis}

Each experiment assay was conducted in 6 repetitions and presented as average value and standard deviation. The statistical analysis software using SPSS with a version of 16.0. Data were analyzed using analysis of variance (ANOVA) followed by Post Hoc Tukey test when required with a level of significance of $\mathrm{p}<0.05$.

\section{RESULTS AND DISCUSSION}

\section{Identification Plant and Extraction Yield}

The results of the identification of plants showed the test plant used was Dioscorea pyrifolia Kunth. with the Dioscoreaceae of the family in letter number 737 / IPH.1.01 / If.07 / III / 2016. In this study, the effect of variations of extraction solvents for extraction yield can be seen in Table-1. In table showed the components of chemical compounds that are more polar than the components of non-polar chemical compounds.

Table-1:The percentage yield of various extracts using percolation method in different solvents

\begin{tabular}{c|c|c|c}
\hline Extract & Simplicia Powder Weight $(\mathrm{g})$ & Extract Weight $(\mathrm{g})$ & \% Yield \\
\hline$n$-hexane & $500 \mathrm{~g}$ & 1.5676 & 0.31 \\
\hline ethyl acetate & $500 \mathrm{~g}$ & 18.1239 & 3.63 \\
\hline methanol & $500 \mathrm{~g}$ & 90.1756 & 18.04 \\
\hline
\end{tabular}

Table-1 showed that extraction using more polar solvents produced the highest extract. According to previous research ${ }^{33}$, the solvent used during extraction will affect the acquisition of the extract, but not the impact on the biological activity produced. By using the solubility principle, components of plant chemical compounds with various variations in polarity will be able to find using the right solvent ${ }^{6}$. Extraction with solvents of increasing polarity (hexane-ethyl acetate-methanol) to ensure that a wide polarity range of compounds could be extracted..$^{25}$

\section{Phytochemical Analysis of Extract Using Thin Layer Chromatography (TLC)}

Results of TLC profile of hexane, ethyl acetate and methanol extract from percolation method using a stratified solvent indicated different chromatogram patterns (Table-2).

Table-2: Chemical Compound Analysis of Extracts Using Thin Layer Chromatography (TLC)

\begin{tabular}{|c|c|c|c|c|c|}
\hline \multirow[b]{2}{*}{ Extract } & \multirow[b]{2}{*}{ Mobile Phase } & \multicolumn{4}{|c|}{ Profile Chromatogram } \\
\hline & & $\begin{array}{l}\text { Detection using } \\
\text { Sulfuric Acid in } \\
\text { Methanol }(10 \%)\end{array}$ & $\begin{array}{l}\text { Detection using } \\
\text { Dragendorff }\end{array}$ & $\begin{array}{l}\text { Detection using } \\
\text { Ferric Chloride } \\
5 \%\end{array}$ & $\begin{array}{l}\text { Detection using } \\
\text { Liebermann- } \\
\text { Burchard }\end{array}$ \\
\hline hexane & $\begin{array}{c}n \text {-hexane:ethyl } \\
\text { acetate }(7: 3)\end{array}$ & $\begin{array}{l}0.90(\mathrm{~g}) \\
0.80(\mathrm{y}) \\
0.75(\mathrm{~b}) \\
0.63(\mathrm{y}) \\
0.58(\mathrm{lg}) \\
0.50(\mathrm{lg}) \\
0.28(\mathrm{p}) \\
0.05(\mathrm{y}) \\
\end{array}$ & not visible & $\begin{array}{c}0.90(\mathrm{~g}) \\
0.75(\mathrm{~g}) \\
0.58(\mathrm{yg})\end{array}$ & $\begin{array}{c}0.80(\mathrm{~g}) \\
0.70(\mathrm{~g}) \\
0.50(\mathrm{lp}) \\
0.28(\mathrm{lp}) \\
0.05(\mathrm{p})\end{array}$ \\
\hline ethyl acetate & $\begin{array}{c}n \text {-hexane:ethyl } \\
\text { acetate }(3: 7)\end{array}$ & $\begin{array}{c}0.87(\mathrm{p}) \\
0.77(\mathrm{p}) \\
0.75(\mathrm{y}) \\
0.52(\mathrm{y}) \\
0.31(\mathrm{~b}) \\
0.25(\mathrm{lb}) \\
0.16(\mathrm{~g}) \\
0.15(\mathrm{~g}) \\
0.12(\mathrm{~g}) \\
0.08(\mathrm{dg})\end{array}$ & $\begin{array}{l}0.52(\mathrm{lg}) \\
0.31(\mathrm{lg}) \\
0.25(\mathrm{lb}) \\
0.15(\mathrm{lb}) \\
0.12(\mathrm{lb}) \\
0.08(\mathrm{lb})\end{array}$ & $\begin{array}{c}0.87(\mathrm{~g}) \\
0.77(\mathrm{~b}) \\
0.75(\mathrm{~b}) \\
0.25(\mathrm{~b}) \\
0.15(\mathrm{~g}) \\
0.08(\mathrm{yg})\end{array}$ & $\begin{array}{l}0.87(\mathrm{~g}) \\
0.77(\mathrm{~g}) \\
0.75(\mathrm{p}) \\
0.52(\mathrm{p}) \\
0.31(\mathrm{~g}) \\
0.16(\mathrm{lb}) \\
0.12(\mathrm{p}) \\
0.08(\mathrm{lb})\end{array}$ \\
\hline methanol & $\begin{array}{c}n \text {-hexane:ethyl } \\
\text { acetate }(3: 7)\end{array}$ & $\begin{array}{l}0.94(\mathrm{~b}) \\
0.90(\mathrm{~g})\end{array}$ & $\begin{array}{l}0.63(\mathrm{br}) \\
0.44(\mathrm{lbr})\end{array}$ & $\begin{array}{l}0.90(\mathrm{~g}) \\
0.87(\mathrm{~b})\end{array}$ & $\begin{array}{l}0.94(\mathrm{p}) \\
0.91(\mathrm{p})\end{array}$ \\
\hline
\end{tabular}


RASĀYAN J. Chem.

Vol. 13 | No. 3 |1894-1903| July - September | 2020

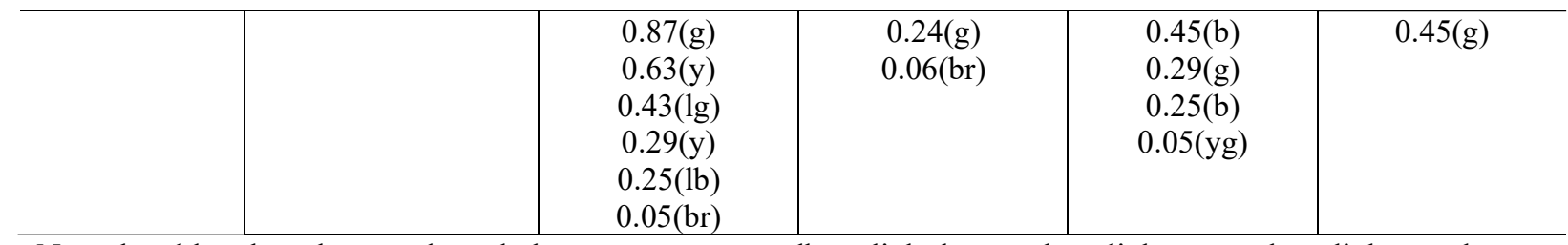

Note: $\mathrm{b}=$ blue, $\mathrm{br}=$ brown, $\mathrm{dg}=$ dark green, $\mathrm{g}=$ green, $\mathrm{lbr}=$ light brown, $\mathrm{lg}=$ light green, $\mathrm{lp}=$ light purple, $\mathrm{p}=$ purple, $\mathrm{y}=$ yellow, $\mathrm{yg}=$ yellowish green

Table-2 showed the differences in the chromatogram patterns of each extract due to the use of different solvents. The components of chemical compounds in the extract produce $\mathrm{Rf}$ and color values for each extract due to the difference between the interest of the chemical compounds in the extract in the stationary phase and the difference in solubility in the mobile phase. By changing the components of the mobile phase will be able to determine the best chromatogram pattern marked by the value of $\mathrm{Rf}$ and the most formed stains and clear separation. ${ }^{26-27}$

\section{The Results of Antibacterial Assays}

The antibacterial activity of $D$. pyrifolia extracts against test bacteria determined from the inhibition zone area was presented in Table-3.

Table-3: Zones of inhibition of different Dioscorea pyrifolia Kunth. tuber extract concentrations against selected bacteria

\begin{tabular}{|c|c|c|c|c|c|c|c|c|c|c|c|}
\hline \multirow{3}{*}{$\begin{array}{c}\text { Bacterial } \\
\text { Strains }\end{array}$} & \multirow{3}{*}{ Solvent } & \multicolumn{10}{|c|}{ Inhibition Zone Diameter (IZD: mm), including Cork Borer (6 mm) } \\
\hline & & \multicolumn{8}{|c|}{ Extracts Concentration $(\mathrm{mg} / \mathrm{mL})$} & \multirow{2}{*}{$\begin{array}{c}\text { Positive } \\
\text { control }\end{array}$} & \multirow{2}{*}{$\begin{array}{l}\text { N. } \\
\text { c. }\end{array}$} \\
\hline & & 125 & 100 & 75 & 50 & 25 & 12.5 & 6.25 & 3.13 & & \\
\hline \multirow{3}{*}{$\begin{array}{l}\text { E. coli } \\
\text { ATCC } \\
25922\end{array}$} & Hexane & $\mathrm{NA}^{\mathrm{p}}$ & $\mathrm{NA}^{\mathrm{p}}$ & $\mathrm{NA}^{\mathrm{p}}$ & $\mathrm{NA}^{\mathrm{p}}$ & $\mathrm{NA}^{\mathrm{p}}$ & $\mathrm{NA}^{\mathrm{p}}$ & $\mathrm{NA}^{\mathrm{p}}$ & $\mathrm{NA}^{\mathrm{p}}$ & $\begin{array}{c}28.10 \pm 0 . \\
58\end{array}$ & NA \\
\hline & $\begin{array}{c}\text { Ethyl } \\
\text { Acetate }\end{array}$ & $\begin{array}{c}18.55 \\
\pm 0.12 \\
\mathrm{a}\end{array}$ & $\begin{array}{c}17.30 \\
\pm 0.05 \\
\text { b }\end{array}$ & $\begin{array}{c}16.11 \\
\pm 0.17 \\
\text { b,c }\end{array}$ & $\begin{array}{c}14.60 \\
\pm 0.07 \\
\text { f,g }\end{array}$ & $\begin{array}{c}12.30 \\
\pm 0.09 \\
\mathrm{k}, 1\end{array}$ & $\begin{array}{c}10.50 \\
\pm 0.05 \\
\mathrm{n}\end{array}$ & $\begin{array}{l}9.60 \pm \\
0.09^{\circ}\end{array}$ & $\mathrm{NA}^{\mathrm{p}}$ & $\begin{array}{c}29.27 \pm 0 \\
52\end{array}$ & NA \\
\hline & $\begin{array}{c}\text { Methano } \\
1\end{array}$ & $\begin{array}{c}15.08 \\
\pm 0.13 \\
\text { e,f }\end{array}$ & $\begin{array}{c}13.35 \\
\pm \underset{\mathrm{i}, \mathrm{j}}{0.05}\end{array}$ & $\begin{array}{c}12.83 \\
\pm 0.15 \\
\mathrm{j}, \mathrm{k}\end{array}$ & $\begin{array}{c}12.30 \\
\pm 0.09 \\
\mathrm{k}, \mathrm{l}\end{array}$ & $\begin{array}{c}10.00 \\
\pm 0.05 \\
\mathrm{n}, \mathrm{o}\end{array}$ & $\mathrm{NA}^{\mathrm{p}}$ & $\mathrm{NA}^{\mathrm{p}}$ & $\mathrm{NA}^{\mathrm{p}}$ & $\begin{array}{c}27.43 \pm 1 \\
22\end{array}$ & NA \\
\hline \multirow{3}{*}{$\begin{array}{c}\text { S. aureus } \\
\text { ATCC } \\
6538\end{array}$} & Hexane & $\mathrm{NA}^{\mathrm{p}}$ & $\mathrm{NA}^{\mathrm{p}}$ & $\mathrm{NA}^{\mathrm{p}}$ & $\mathrm{NA}^{\mathrm{p}}$ & $\mathrm{NA}^{\mathrm{p}}$ & $\mathrm{NA}^{\mathrm{p}}$ & $\mathrm{NA}^{\mathrm{p}}$ & $\mathrm{NA}^{\mathrm{p}}$ & $\begin{array}{c}31.64 \pm 0 . \\
45\end{array}$ & $\mathrm{NA}$ \\
\hline & $\begin{array}{c}\text { Ethyl } \\
\text { Acetate }\end{array}$ & $\begin{array}{c}14.11 \\
\pm 0.21 \\
\mathrm{~g}, \mathrm{~h}\end{array}$ & $\begin{array}{c}13.75 \\
\pm 0.05 \\
\text { h,i }\end{array}$ & $\begin{array}{c}12.63 \\
\pm 0.12 \\
\mathrm{k}\end{array}$ & $\begin{array}{c}12.40 \\
\pm 0.36 \\
\mathrm{k}, 1\end{array}$ & $\begin{array}{c}11.60 \\
\pm 0.36 \\
\mathrm{~m}\end{array}$ & $\mathrm{NA}^{\mathrm{p}}$ & $\mathrm{NA}^{\mathrm{p}}$ & $\mathrm{NA}^{\mathrm{p}}$ & $\begin{array}{c}32.31 \pm 0 . \\
14\end{array}$ & $\mathrm{NA}$ \\
\hline & $\begin{array}{c}\text { Methano } \\
1\end{array}$ & $\begin{array}{l}17.08 \\
\pm 0.18 \\
\mathrm{~b}\end{array}$ & $\begin{array}{c}16.35 \\
\pm 0.31 \\
\mathrm{c}\end{array}$ & $\begin{array}{c}15.56 \\
\pm 0.14 \\
\mathrm{~d}, \mathrm{e}\end{array}$ & $\begin{array}{c}14.70 \\
\pm 0.09 \\
\text { f,g }\end{array}$ & $\begin{array}{c}11.90 \\
\pm 0.05 \\
1, \mathrm{~m}\end{array}$ & $\mathrm{NA}^{\mathrm{p}}$ & $\mathrm{NA}^{\mathrm{p}}$ & $\mathrm{NA}^{\mathrm{p}}$ & $\begin{array}{c}30.64 \pm 0 \\
86\end{array}$ & $\mathrm{NA}$ \\
\hline
\end{tabular}

Note: values were expressed as mean value standard deviation $(n=6)$ for the same treatment in millimeters. Numbers indicated the mean diameters of inhibition zone of six experiments \pm SD in millimeters, NA: no activity, positive control $=$ chloramphenicol $(2.5 \mathrm{mg} / \mathrm{mL})$, negative control (N.c.) = a mixture of dimethylsulfoxide (DMSO) and ethanol, means with different superscripts are statistically significantly different between means at $\mathrm{p}<0.05, E$. coli $=$ Escherichia coli, S. aureus $=$ Staphylococcus aureus

Extracts obtained from different organic solvents have different phytoconstituents and amounts, this results in different antibacterial activity in each test bacteria ${ }^{33}$. Hexane tuber extract of $D$. pyrifolia did not provide inhibitory activity on test bacteria. The same results were shown in previous studies ${ }^{34}$ namely that hexane extracts from Nicolaia speciosa fruit did not provide inhibitory activity against E. coli, B. cereus and $P$. aeruginosa by showing that the extract has a chemical component of steroids, triterpenoids, alkaloids and glycosides. The mechanism does not fully occur, because, from the results of research conducted on the components of compounds produced by A. niger, it showed that chemical components 
RASĀYAN J. Chem.

Vol. 13 | No. 3 |1894-1903| July - September | 2020

do not work on cell walls, but work elsewhere, which causes damage to cell membranes ${ }^{35}$. Antibacterial compounds can also work on the integrity of cell membranes, causing damage and even cell death ${ }^{36}$. In the results of this study, besides getting information about the role of ethyl acetate extract (which tends to be more non-polar than methanol), it has more influence on E. coli, but methanol extract was given stronger inhibitory activity against $S$. aureus, then the possibility of $D$. pyrifolia tuber extract has activity broad spectrum with causing damage to cell membranes. To ensure the antibacterial activity of ethyl acetate extract, a minimum inhibitory concentration (MIC) and a minimum bactericidal concentration (MBC) were determined, the results of which can be seen in Table-4.

According to previous research ${ }^{37}$ the determination of MIC and MBC values in a plant will tend to be obtained lower MIC values than the MBC value which indicates that the extract is bacteriostatic at lower concentrations and bactericidal extracts at higher concentrations. $\mathrm{MBC}$ is used to determine the lowest concentration of antibacterial agents that cause no colony growth in solid media. MBC is an important parameter in determining whether an antibacterial agent can be bacteriostatic or bactericidal when the $\mathrm{MBC} / \mathrm{MIC}$ ratio is calculated. When the MBC / MIC ratio is greater than 4, the effect becomes bacteriostatic and when the ratio is less than or equal to 4 , the effect becomes bactericidal ${ }^{38}$. Based on the results of this study, ethyl acetate extract has a bactericidal effect on $E$. coli (ratio value of 2) and $S$. aureus (ratio value of 1.5). These results are important because they confirm that D. pyrifolia tuber of ethyl acetate extract not only inhibits growth (MIC), but also kills $99.9 \%$ of the test bacterial population.

\section{The Results of Determination Leakage of Cellular Metabolites}

The results of cell leakage determination against Escherichia coli and Staphylococcus aureus by measuring the release of cellular material can be seen in Fig.-1.

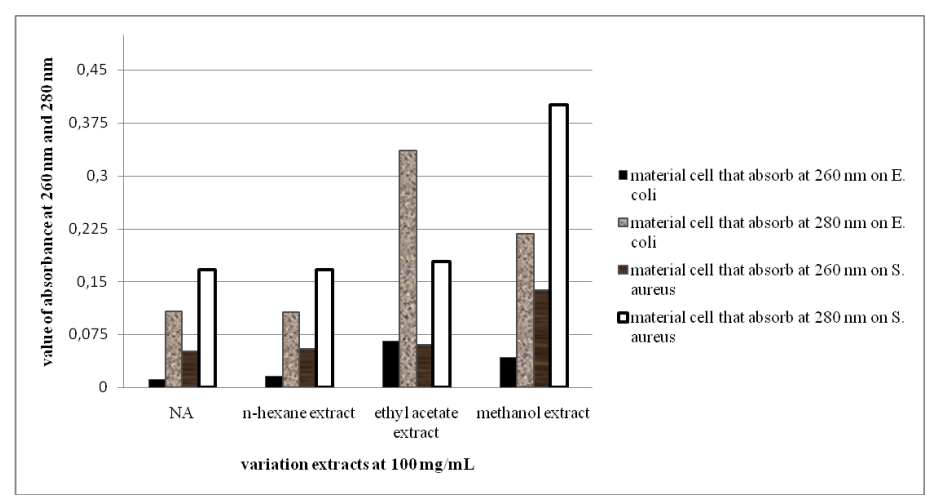

Fig.-1: Absorbance of Supernatant at $260 \mathrm{~nm}$ and $280 \mathrm{~nm}$ from E. coli and S. aureus after each extract was added at $100 \mathrm{mg} / \mathrm{mL}, \mathrm{NA}=$ supernatant of $E$. coli and $S$. aureus without treatment

Cell leakage was shown in the increase in absorbance that occurred from all treatments compared with test bacterial cells without the administration of extracts (NA). Determination of bacterial cell wall/membrane leakage was analyzed by measuring absorbance at $260 \mathrm{~nm}$ (nucleic acid) and $280 \mathrm{~nm}$ (protein) wavelengths ${ }^{31}$. Leakage of cytosolic constituents (absorbed material at wavelengths of 260 and $280 \mathrm{~nm}$ ) which is increasing from the control treatment of Staphylococcus aureus cells and some gramnegative bacteria that have been studied ${ }^{39}$ indicate that antimicrobial compounds from natural materials can interfere with permeability layer of microbial membrane structure. Further added to other studies ${ }^{40-41}$ that increased absorbance at wavelengths of 260 and $280 \mathrm{~nm}$ indicates damage to cell membranes and leakage of intracellular nucleotides as well as protein material in growth media. According to previous study ${ }^{42}$, the polyphenol group is the largest plant chemical group including flavonoid and tannin that can damage bacterial cell membranes. Based on literature ${ }^{43-44}$, cell leakage is caused by interactions between antibacterial compounds and components of the outer membrane of bacterial cells, especially the phospholipid component that forms pores on the bacterial cell membrane. 
RASĀYAN J. Chem.

Vol. 13 | No. 3 |1894-1903| July - September | 2020

The Results of Determination of $\mathrm{Ca}^{2+}$ and $\mathrm{K}^{+}$Ions Leakage

The results of the leakage test of metal ions of ethyl acetate extract against supernatant cells of Escherichia coli and Staphylococcus aureus can be seen in Fig.-2. The figure showed that using various extracts treatments for test bacteria caused an increase in the amount of $\mathrm{Ca}^{2+}$ and $\mathrm{K}^{+}$ions released by Escherichia coli and Staphylococcus aureus compared with test bacteria without the addition of extracts (NA). According to the previous study ${ }^{45}$, the release of $\mathrm{Ca}^{2+}$ and $\mathrm{K}^{+}$ions indicated that cell wall instability occurs. Ion $\mathrm{K}^{+}$has an important part in animating cytoplasmic enzymes, including turgor emphasis and organizing cytoplasmic $\mathrm{pH}$. While $\mathrm{Ca}^{2+}$ ions function to connect lipopolysaccharides (LPS) to bacterial cell walls, so the release of $\mathrm{Ca}^{2+}$ ions disrupts cell wall stability and can result in bacterial death. ${ }^{46-47}$

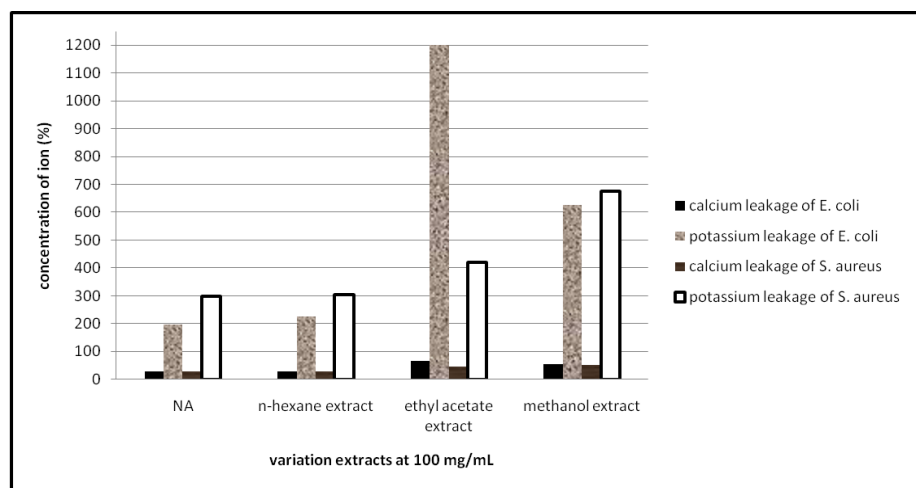

Fig.-2: Effect of Various Extracts of D. pyrifolia tuber on Calcium and Potassium Leakage of E. coli and S. aureus, $\mathrm{NA}=$ supernatant of $E$. coli and $S$. aureus without treatment

\section{The Results of Scanning Electron Microscopy (SEM) Analysis}

As shown in Fig.-3, the results showed that the cell form of Escherichia coli and Staphylococcus aureus without incubation with the addition of extracts, displayed a whole and subtle surface while after being incubated with various extract treatments, cell form of bacterial strains appeared granular with a scratched appearance.

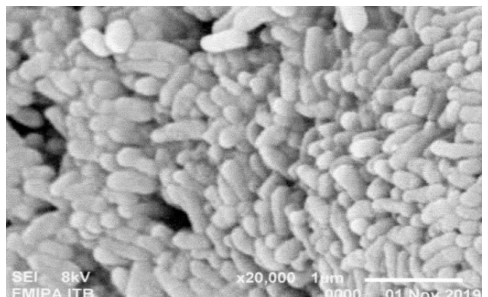

(a)

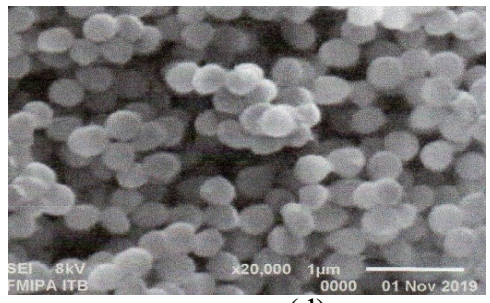

(d)

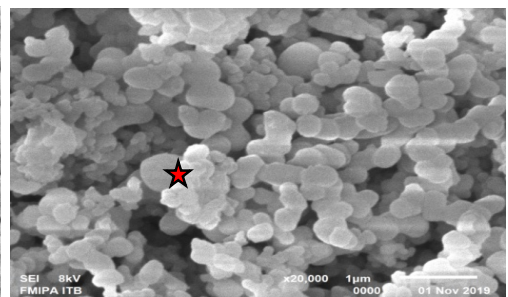

(b)

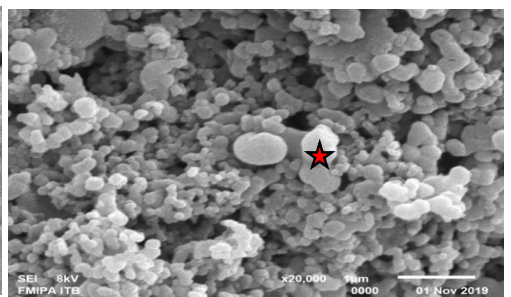

(e)

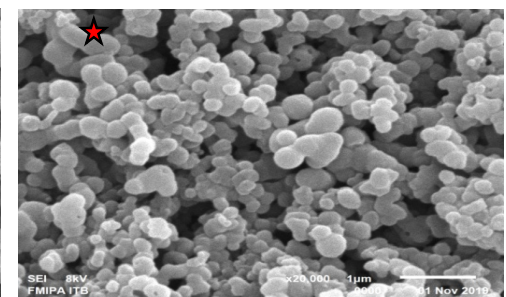

(c)

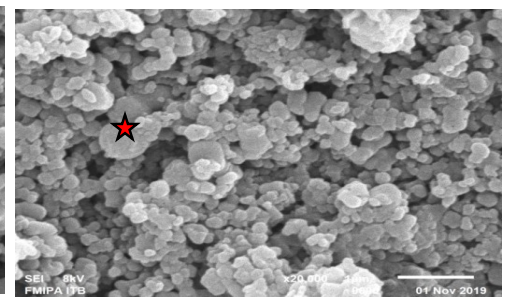

(t)

Fig.-3: Bacterial cell surface morphology was observed with SEM at a magnification of 20000x using the Scanning Electron Microscope (JEOL-JSM-6510LA) (a). Escherichia coli cells without treatment, (b). Escherichia coli cells after exposure to the ethyl acetate extract at a concentration of $100 \mathrm{mg} / \mathrm{mL}$, (c). Escherichia coli cells after exposure to the methanol extract at a concentration of $100 \mathrm{mg} / \mathrm{mL}$, (d). Staphylococcus aureus cells without treatment, (e). Staphylococcus aureus cells after exposure to the ethyl acetate extract at a concentration of $100 \mathrm{mg} /$ $\mathrm{mL}$, (f). Staphylococcus aureus cells after exposure to the ethyl acetate extract at a concentration of $100 \mathrm{mg} / \mathrm{mL}$ 
RASĀYAN J. Chem.

Vol. 13 | No. 3 |1894-1903| July - September | 2020

Table-4: MIC and MBC Value of Ethyl Acetate Extracts Against Bacteria

\begin{tabular}{c|c|c|c|c}
\hline \multirow{2}{*}{ Strain Bacteria } & \multicolumn{2}{|c|}{ Ethyl Acetate Extract } & \multicolumn{2}{c}{$\begin{array}{c}\text { Chloramphenicol } \\
\text { (Positive Blank) }\end{array}$} \\
\cline { 2 - 5 } & MIC $(\mathrm{mg} / \mathrm{mL})$ & MBC $(\mathrm{mg} / \mathrm{mL})$ & MIC(mg/mL) & $\mathrm{MBC}(\mathrm{mg} / \mathrm{mL})$ \\
\hline Escherichia coli ATCC 25922 & 12.5 & 25 & 0.09 & 0.19 \\
\hline Staphylococcus aureus ATCC 6538 & 50 & 75 & 0.05 & 0.09 \\
\hline
\end{tabular}

According to previous research ${ }^{48}$, changes in the structure and permeability of cell membranes seen using SEM are thought to be due to antibacterial chemical substances acting on the cytoplasm, so that cells become dehydrated, stop developing and eventually break. In previous studies ${ }^{49}$ added that besides membrane damage that has been observed in cell morphological disorders, it is also influenced by enzymatic degradation so that cells become lysis. The mechanism of action of plant chemical components including polyphenol groups is related to obstruction of hydrolytic enzymes (e.g. proteases) or other interactions that disable microorganism adhesion, protein envelope cell transport and non-characteristic interactions with carbohydrates ${ }^{32}$. According to previous report ${ }^{50}$, treated bacterial cells tend to blister and degrade. Degradation of bacterial cells is caused by damage to cytoplasmic membrane proteins, damage between protein-protein bonds, cell leakage and cytoplasmic coagulation.

\section{CONCLUSION}

The results of research that have been carried out are known to extract ethyl acetate and methanol which have an antibacterial mechanism against Escherichia coli and Staphylococcus aureus. The extraction method that produces the strongest antibacterial activity is the multilevel percolation method using ethylacetate as a solvent. The chemical compounds found in ethylacetate extract are polyphenol compounds, such as glycosides, alkaloids, tannins and flavonoids. The mechanism of bacterial cell leakage caused by $D$. pyrifolia tuber extract can be proven by ultraviolet spectrophotometry, atomic absorption spectrophotometer (AAS) and Scanning Electron Microscope (SEM).

\section{ACKNOWLEDGEMENT}

All the authors would like to thank the Ministry of Research, Technology and Higher Education in Indonesia for part of the funding this research through the BPPDN Scholarship Program starting from contract 2015.

\section{REFERENCES}

1. J. D. F. Hale and R. E. W. Hancock, Future Drugs Ltd - Expert Review of Anti Infective Therapy, 5(6), 951(2007), DOI:10.1586/14787210.5.6.951

2. V. Hoerr, G. E. Duggan, L. Zbytnuik, K. K. H. Poon, C. Große, U. Neugebauer, K. Methling, B. Löffler and H. J. Vogel, BMC Microbiology, 16(82), 1(2016), DOI:10.1186/s12866-016-0696-5

3. P. G. Mwitari, P. A. Ayeka, J. Ondicho, E. N. Matu and C. C. Bii, Plos One, 8(6), 1(2013), DOI:10.1371/journal.pone.0065619

4. N. S. Ncube, A. J. Afolayan and A. I. Okoh, African Journal of Biotechnology, 7(12), 1797(2008), DOI:10.5897/AJB07.613

5. D. Savoia, Future Medicine Ltd - Future Microbiol, 7(8), 979(2012), DOI:10.2217/fmb.12.68

6. R. A. Vargas, C. F. P. Malacara and V. L. Petricevich, MDPI Antioxidants. 5(45), 1(2016), DOI: $10.3390 /$ antiox 5040045

7. A. Chandrasekara and T. J. Kumar, Hindawi Publishing Corporation - International Journal of Food Science, 2016(Article ID 3631647), 1(2016), DOI:10.1155/2016/3631647

8. J. I. Odimegwu, O. Odukoya, R. K. Yadav, C. S. Chanotiya, S. Ogbonnia and N. S. Sangwan, Hindawi Publishing Corporation - The Scientific World Journal, 2013(943598), 1(2013), DOI:10.1155/2013/943598

9. V. Mierza, Rosidah, G. Haro, and D. Suryanto, Journal of Innovations in Applied Pharmaceutical Science, 4(1), 1(2019)

10. M. A. Sonibare and R. B. Abegunde, Journal of Applied Biosciencesi, 51, 3583 (2012)

11. S. Chandra, S. Saklani and A. P. Mishra, International Journal of Herbal Medicine, 1(4), 67(2013) 
12. P.S. Sandhu, B. Singh, V. Gupta, P. Bansal and D. Kumar. Journal of Pharmaceutical Science and Research, 3(4), 1127 (2011)

13. S. Ghosh, A. Derle, M. Ahire, P. More, S. Jagtap, S. D. Phadatare, A. B. Patil, A. M. Jabgunde, G. K. Sharma, V. S. Shinde, K. Pardesi, D. D. Dhavale and B. A. Chopade, Plos One, 8(12), 1(2013), DOI:10.1371/journal.pone.0082529

14. S. Ghosh, P. More, A. Derle, A. B. Patil, P. Markad, A. Asok, N. Kumbhar, M. L. Shaikh, B. Ramanamurthy, V. S. Shinde, D. D. Dhavale and B. A. Chopade, Plos One, 9(9), 1(2014), DOI:10.1371/journal.pone.0106039

15. H. Yang, H. W. Yin, X. W. Wang, Z. H. Li, Y. P. Shen and X. B. Jia, Pharmacognosy Magazine, 11(43), 636(2015), DOI:10.4103/0973-1296.160472

16. T. Yi, L. L. Fan, H. L. Chen, G. Y. Zhu, H. M. Suen, Y. N. Tang, L. Zhu, C. Chu, Z. Z. Zhao and H. B. Chen, BMC Biochemistry, 15(19), 1(2014), DOI:10.1186/1471-2091-15-19

17. H. K. Go, M. M. Rahman, G. B. Kim, C. S. Na, C. H. Song, J. S. Kim, S. J. Kim, and H. S. Kang, Nutrients, 7(10), 8532(2015), DOI:10.3390/nu7105411

18. T. Liu, H. Yu, C. Liu, Y. Bao, X. Hu, Y. Wang, B. Liu, Y. Fu, S. Tang and F. Jin, Journal of Industrial Microbiology, 40(3), 427(2013), DOI:10.1007/s10295-013-1246-X

19. J. O. Olayemi and E. O. Ajaiyeoba, African Journal of Biotechnology, 6(16), 1913(2007), DOI:10.5897/AJB2007.000-2289

20. G.N. Poornima and R. V. Ravishankar, 2009. African Journal of Biotechnology, 8(6), 971(2009)

21. G. Prakash and B. B. Hosetti, Toxicology International, 19(2), 100(2012), DOI:10.4103/09716580.97195

22. M. C. Reddy, K. S. R. Murthy, A. Srilakhsmi, K. R. S. S. Rao and T. Pullaiah, African Journal of Biotechnology, 14(3), 222 (2015), DOI:10.5897/AJB2013.13299

23. V. Kuete, R. B. Teponno, A. T. Mbaveng, L. A. Tapondjou, J. J. M. Meyer, L. Barboni and N. Lall, BMC Complementary and Alternative Medicine, 12(228), 1 (2012), DOI:10.1186/1472-6882-12-228

24. T. P. Versiati, A. F. Hafid and A. Widyawaruyanti, Jurnal Farmasi dan Ilmu Kefarmasian Indonesia, 1(1), 16 (2014).

25. K. S. Banu and L. Cathrine, International Journal of Advanced Research in Chemical Science, 2(4), 25(2015)

26. L. Cai, 2014, Current Protocols Essential Laboratory Techniques in Thin Layer Chromatography, John Wiley \& Sons, Inc, New York, 8(1), pp. 6.3.1-6.3.18

27. E. Matysik, A. Wofniak, R. Paduch, R. Rejdak, B. Polak and H. Donica, Journal of Analytical Methods in Chemistry, 2016(1813581), 1 (2016), DOI:10.1155/2016/1813581

28. Masfria, G. Haro, Nerdy, V. Mierza, H. S. Wahyuni and Y. M. Permata, International Journal of PharmTech Research, 9(11), 110 (2016)

29. Masfria, G. Haro and V. Mierza, Rasayan Journal of Chemistry, 12(2), 1002(2019), DOI:10.31788/RJC.2019.1225153

30. J. Boateng and K. N. Diunase, Molecules, 2015(20), 16068(2015), DOI: $10.3390 /$ molecules200916068

31. Miksusanti, B. S. L. Jenie, B. P. Priosoeryanto, R. Syarief, and G. T. Rekso, HAYATI Journal of Biosciences, 15(2), 56 (2008), DOI: 10.4308/hjb.15.2.56

32. P. W. Su, C. H. Yang, J. F. Yang, P. Y. Su and L. Y. Chuang, Molecules, 2015(20), 11119(2015), DOI:10.3390/molecules200611119

33. H. Padalia and S. Chanda, Applied Microbiology: Open Access, 1(1), 1(2015), DOI:10.4172/24719315.1000106

34. R. Naufalin and S. R. Herastuti, International Food Research Journal, 24(1), 379(2017)

35. A. P. Wulandari, N. Primastia and J. N. Sajuti, AIP Conference Proceedings, 1744(1), 020005-1 (2016), DOI:10.1063/1.4953479

36. Aminah, E.R. Nugraheni and A. Yugatama, IOP Conference Series: Materials Science and Engineering, 333(012080), 1 (2018), DOI:10.1088/1757-899X/333/1/012080

37. B. A. Shanab, G. Adwan, N. Jarrar, A. A. Hijleh and K. Adwan, Turkish Journal of Biology, 30, 195 (2006). 
RASĀYAN J. Chem.

Vol. 13 | No. 3 |1894-1903| July - September | 2020

38. E. N. G. Alamilla, M. G. Cortazar, B. V. Carranza, M. A. R. Jacobo, C. A. H. Corredor, D. O. Ramírez, A. Z. Bastida and N. R. Perez, Molecules, 24(2992), 1(2019), DOI: $10.3390 /$ molecules24162992

39. A. F. Raja, F. Ali, I. A. Khan, A. S. Shawl, D. S. Arora, B. A. Shah and S. C. Taneja, BMC Microbiology, 11(54), 1 (2011)

40. A. Dua, G. Gaurav, S. Balkar, and R. Mahajan, International Journal of Research in Ayurveda Pharmacy, 4(1), 104(2013), DOI:10.7897/2277-4343.04136

41. R. M. Hanafiah, W. S. Aqma, W. A. Yaacob, Z. Said and N. Ibrahim, Malaysian Journal of Microbiology, 11(2), 199 (2015), DOI: 10.21161/mjm.13314

42. U.S.M. Rao, M. Abdurrazak and K.S. Mohd, Malaysian Journal of Analytical Sciences, 20(5), 1181(2016), DOI: 10.17576/mjas-2016-2005-25

43. M. Oussalah, S. Caillet and M. Lacroix, Journal of Food Protectio, 69(5), 1046(2006), DOI:10.4315/0362-028x-69.5.1046

44. Y. Wu, J. Bai, K. Zhong, Y. Huang, H. Qi, Y. Jiang and H. Gao, MDPI Molecules, 21(1084), 1 (2016), DOI:10.3390/molecules21081084

45. R. Fauziyya, L. H. Nurani and N.Sulistyani, Traditional Medicine Journal, 22(3), 166(2017), DOI: $10.22146 /$ mot. 31550

46. H. Nikaido and M. Vaara, Microbiological Reviews, 49(1), 1(1985)

47. S. D. Cox, C. M. Mann, J. L., Markham, J. E. Gustafson, J. R. Warmington and S. G. Wyllie, Molecules, 2001(6), 87(2001), DOI:10.3390/60100087

48. C. $\mathrm{Li}$ and J. Yu, Asian Journal of Chemistry, 26(22), 7741(2014), DOI:10.14233/ajchem.2014.17740

49. J. K. Patra, G. Das and K. H. Baek, Botanical Studies, 56(13), 1(2015), DOI:10.1186/s40529-0150093-7

50. I. Kaya, N. Yiğit and M. Benli, African Journal of Traditional, Complementary and Alternative Medicines, 5(4), 363(2008), DOI:10.4314/ajtcam.v5i4.31291

[RJC-5864/2020] 